\title{
Reimagining quality in early childhood
}

(Editorial: Contemporary Issues in Early Childhood 2016, Vol. 17(1) 3-7, 2016)

This special issue brings together a collection of rich, complex and challenging contributions that attempt to offer generative approaches to reconfigure what might constitute 'quality' within early years education. The issue came about from a shared concern about what Moss (this issue) refers to as the 'gravitational pull' of quality in early childhood education; debates about quality have existed for a considerable time and, despite rigorous critique, remain resolute. This issue aims to revisit and extend the groundbreaking work undertaken by Gunilla Dahlberg, Peter Moss and Alan Pence $(1999,2007)$ in Beyond Quality in Early Childhood Education and Care: Postmodern Perspectives and in the subsequent revised edition. In both texts, the authors made the astute observation that the concept and language of quality cannot accommodate issues such as diversity and multiple perspectives, contextual specificity and subjectivity. They argue that we must 'go beyond the concept of quality' (Dahlberg et al., 2007: 6) and, in so doing, suggest working with a new concept: 'meaning making'. As noted by the authors:

meaning making can be construed within the notion of evaluation where it is implicated within and an integral part of a democratic process of interpretation. As such it is a process that involves making practice visible and thus subject to reflection, dialogue and argumentation, leading to a judgement of value, contextualised and provisional because it is always subject to contestation. (Dahlberg et al., 2007: ix)

This special issue might therefore be understood as a practice of contestation where theoretical work that is emanating from new materialism and post-humanism be brought to 'quality' in order to interrogate it, whilst also opening it in ways where diversity, multiple perspectives, contextual specificity and subjectivity can be attended to.

As stated in the call for papers for this issue, the aim is to breathe new life into a concept, which wields immense power to the detriment of a great many young people, their families and those who work in early years contexts. Globally, government policy and politics have sought to imbue it with stability, familiarity and attainability. Yet, paradoxically, whilst attempting to pin 'quality' down so as to give it meaning, it has, in the process, become meaningless. As Massumi (1993: 10) points out, a 'thing' like 'quality' has as 'many meanings as there are forces capable of seizing it'. While, for some, searching for the 'many meanings' of 'quality' has left us with nothing more than a quest for 'fool's gold' (Penn, 2011: xi), to be abandoned the sooner the better, we are interested in this quest and in the off-mainstream (hence foolish?) views of the conceptual jesters, the theoretical vagabonds and the methodological good-for-nothings, and their challenges to the powerful concept of 'quality'. This journal issue therefore aims to explore juxtapositions between meanings of 'quality' and 'forces', and, in so 
doing, make clear the toxic interests when some forms of (so-called) quality are valorised, whilst others are at best ignored or at worse demonised.

The challenge of putting new materialism and post-humanism to work requires significant ontological and epistemological shifts. Nevertheless, it is only by shifting the ground on which specific knowledge claims are made that we can potentiate a different logic which, in turn, can alter both thinking and, importantly, practice. Thus, this special issue will resolutely refute a general idea or model of what constitutes quality. Instead, it will situate 'quality' within a 'zone of indeterminacy' (Massumi, 1993: 99) and, in so doing, free it from habitual assumptions - assumptions that, in our view, delimit and police the manifest possibilities of what might constitute quality. So, whilst we perceive the overall remit of this special issue to offer insightful critique, we are nevertheless mindful of Deleuze when he noted that:

To criticize is only to establish that a concept vanishes when it is thrust into a new milieu, losing some of its components, or acquiring others that transform it. But those who criticize without creating, those who are content to defend the vanished concept without being able to give it the forces it needs to return to life, are the plague of philosophy. (Deleuze and Guattari, 1994: 108).

Forewarned by Latour that critique on its own has 'run out of steam', we want to nevertheless take up Braidotti's (2012: 6) challenge that there is an 'intimate connection between critique and creation'. We argue that it is by wrangling and plundering this 'connection' that we are enabled to imagine sustainable alternatives. Thus, this special issue will go beyond a deconstruction of 'quality', where there are possibilities for an ethics of (re)affirmation.

Befittingly, Peter Moss opens this issue with an article entitled 'Why can't we get beyond quality?' His article offers a useful outline of the 'problem with quality' as set out in Beyond Quality in Early Childhood Education and Care: Postmodern Perspectives (Dahlberg et al., 1999, 2007). By summarising the argument for problematising the concept of quality, Moss argues that we must recognise 'quality' is a choice and not a necessity, and, if we choose it, then we must take responsibility for that choice and all that it un/does in the field of early childhood. Lastly, Moss asks: 'Why has it proven so hard to get beyond quality? Why does it exert such a strong gravitational pull?' He wonders if we are on 'a wild goose chase' (Dahlberg et al., 2013: 111) in our attempts to get beyond. As editors, we are hopeful that the contributions in this issue, through experimental and uncertain methods, offer generative illustrative examples of the potential of new materialist and post-humanist ethical onto-epistemologies (Barad, 2012) to go beyond quality as discourses and subjectivities to processes of becoming quality and might mean that we have ceased chasing and instead are becoming-with the goose.

Sonja Arndt and Marek Tesar then attempt to push the deconstruction of quality to further limits. They do this by 'pushing the apparatus of quality "beyond the threshold of sameness" through the conception of 'social movements'. By 'striking through' the social, they de-elevate the importance of the human subject and instead focus on and 
explore the tensions with post-humanist approaches. They shed fresh light on thinking about the intricate web of qualities woven throughout entanglements of subjects, objects and things that constitute 'the sector', and the movements already within the sector (Jones et al., 2014). Making use of theorists including Barad, Bennett, Braidotti, Butler, Haraway and Latour to test and blur the boundaries of the human subject, subjectivity and autonomy, the authors offer a means to (re)think and (re)configure conceptual understandings and theoretical assemblages of 'quality'.

The issue then moves on to encounter a series of articles where this theoretical framing is put to work in a variety of creative and experimental ways. Liz Jones, Nina Rossholt, Thekla Anastasiou and Rachel Holmes draw on data from ethnographic studies in England and Norway to take up quality as a 'weasel' concept, and to work through how it might be better understood as a network of intensities and as processes of becoming. The authors work with Braidotti's concepts of 'nomadic activity' and process ontology, together with Massumi's ideas relating to activist philosophy, to think differently about quality in early childhood contexts. As the title - 'Masticating "quality" and spitting the bits out' - suggests, a focus is placed on the practices, habits and mundanities that are associated with eating food in early childhood settings to question whether it is possible to put aside a universal standard of quality so as to consider other potentialities.

The next article takes us to Canada. In 'Storying practices of witnessing: Refiguring quality in everyday pedagogical encounters', Fikile Nxumalo offers 'small stories' from her arts-based practices as a pedagogista. The article unsettles dominant framings of quality practices by putting to work Haraway's figure of the modest witness as a way of storying everyday pedagogical encounters in childhood settings to think of quality as materialised more-than-human becomings. The article explores descriptive visual and textual accounts as the means to experiment with implicated, responsive and messy practices in order to bring hopeful possibilities for reimagining quality-in-practice that avoid fixed and final resolutions.

Writing in the Australian context, Iris Duhn and Sue Grieshaber attempt to suspend the habitual and contested assumptions associated with the mission for quality in early childhood education and its taken-for-granted common sense-ness. 'Imagining otherwise: A (brief) Darwinian encounter with quality standards' aims to move beyond the limitations of such discourses. The authors do this by rejecting the 'dictatorship of no alternatives' (DONA) (Unger, 2005: 1) in current thinking about quality, and instead take up an exploratory approach in an attempt to imagine otherwise. By working with a rich description of a child/pipe/sand event and applying a DONA-like analysis, the authors use what are habitual practices (observation, quality measurement) and make the familiar less familiar in order to create niches for variations and alternative imaginings of 'quality'.

Focusing on ideas of 'readiness', Katherine Evans goes 'Beyond a logic of quality: Opening space for material-discursive practices of "readiness" in early years education', to explore possibilities encountered through shifting from a 'logic of quality' to a 'space of meaning-making' within early years education. Taking a nursery in England as its 
context, this study aims to challenge normative understandings of quality as the predictable achievement of fixed goals and outcomes. Barad is put to work in this space of meaning-making to create opportunities for renewed understandings and practices of 'readiness'. The author problematises binaries of human/material and discourse/matter to unsettle dominant constructions of 'readiness'. Instead, 'readiness' as a material-affective relation between human and non-human bodies is offered to argue that entangling materiality within a space of meaning-making creates space to challenge the status quo, creating new ways of understanding happenings in early years contexts.

Jenny Ritchie argues that notions of 'quality' in early childhood education have been captured by neo-liberal discourses. In her article, 'Qualities for early childhood care and education in an age of increasing superdiversity and decreasing biodiversity', Ritchie stresses that it is these discourses that perpetuate the western, individualistic, normativising and exploitative attitudes and practices that contribute to the global climate crisis. Via a sequence of short stories based within the early childhood care and education context of Aotearoa (New Zealand), the author illustrates the means by which educators may inadvertently perpetuate this situation or consciously challenge it, by opening up spaces of divergence. By drawing on post-humanist and indigenous theorising, Ritchie offers readers opportunities to consider the ways in which dispositional qualities which holistically engage intra-actively with(in) children's worlds might be fostered.

Maria Viviani's article takes us to Chile, where she invites the reader to explore the 'good early childhood educator' in that context. Research with a range of Chilean early childhood stakeholders and practitioners offers Viviani an opportunity to reconceptualise the 'good early childhood educator'. She explores the dominance of new foreign narratives in the field and the related standardisation of notions of 'professionalism' to offer a critical and alternative viewpoint. Adopting a postmodern approach to grounded theory (situational analysis), the participants' discourses were analysed and compared, together with a diversity of identified elements and human and non-human actors. Shared meanings, conflicts, tensions and local understandings were identified in the data, and cartographic tools were used to illustrate them. The article concludes by offering some possibilities for how this study might inform debates about quality nationally within the early childhood profession in Chile, and more broadly in other spaces and places.

Red Ruby Scarlet offers an Ode to this collection, which raises questions about the potentialities for post-humanist arts-based methods of enquiry to generate new understandings about quality in early childhood. The Ode is intended to be affecting and to act as an 'interrupter'. Red Ruby Scarlet has 'Odelled to the "Qualia of Quality"' in another recent publication (see Osgood et al., 2015), which posed questions about what an Ode is and what an Ode does, and invited readers to engage with the affects the Ode induced. The Ode's contribution to this special issue on quality is to ask: 'What do we do with what quality does in early childhood?' It is a question concerned with the qualia of quality in early childhood, intended to generate affective onto-epistemological challenges and actively and creatively contribute to academic work, arts practice and activism. 
Also concerned with the qualia of quality, Anne Beate Reinertsen's article, entitled 'A Phaedrus baroque art of maintenance or constant fabulating qualia becoming quality', is crafted through three scenes through which to imagine quality otherwise. Drawing on Spinoza, Deleuze and Braidotti, Reinertsen attempts to rhizomatically set everything (lived events, historical determinations, theories, philosophies, stories, concepts, individuals, groups, social formations, her desires) out on a plane of exteriority. Scene One is from Plato's dialogue Phaedrus and is about censuring. Scene Two is from Pirsig's story Zen and the Art of Motorcycle Maintenance: An Inquiry into Values. The third scene is a fabulation that writes qualia as becoming quality to transgress existing, universal measurements of quality. The author argues that early child/hood should ultimately be seen as a matrix of becoming, and early childhood education and care settings as translocal places preparing for future contingent events. Reinertsen is initiating new discourses on childhood - ultimately, children's political subject formations.

This issue would not be complete without a vital contribution from a founding member of those encouraging us to 'go beyond quality'. Gunilla Dahlberg contributes 'An ethicoaesthetic paradigm as an alternative discourse to the quality assurance discourse', in which she analyses the discourse and practices of quality assurance and quality control through neo-liberal governance (i.e. economic rationalities such as new public management, total quality management, public choice and human capital). She offers an alternative to this form of governing in the form of an ethico-aesthetics inspired by Spinoza's concept of 'affect' and the DeleuzoGuattarian 'ontology of immanence'. She argues that this framing creates space for a reconstruction of the pragmatic scene of didactics, as it border-crosses the discourse and practices of 'action at a distance', manipulating the classroom space from outside of the situation by measurements and procedures constructed by others. Besides this, it opens for another construction of the human subject - a processual and event-centred construction of human subjectivity - which also allows for leakages, movement, creativity and hope in the present.

Finally, this special issue benefits from a contribution from a group of educators at The Red House Children's Centre, who consider a reconfiguring of quality and how this has impacted on practice in their early years setting in England. A team of educators composed this piece in order to demonstrate how a move from a formal quantitative strategic plan for the setting to a narrative version, known as 'Violet's Story', sits within the academic debate of quality framed by posthumanist concerns to decentre the human subject. The authors explain how this shift reflects a qualiaic understanding of quality and, in doing so, show how the narrative strategies and techniques deployed embody post-humanist sympathies, taking the reader beyond the subjective to reveal some of the complexities of entanglement that make up a shifting, contextualised understanding of quality. Finally, one practitioner's deep musings on what it can be like to work within a fluid, contextualised understanding of quality make use of recently encountered new materialist and post-humanist concepts. The authors conclude by arguing that more research should follow post-humanist modes of inquiry for a fuller understanding of the corporeal and multisensorial impact that such a reconfiguration of quality might have on early years settings, the experiences of practitioners, children and their families. 
This special issue is, in many respects, a celebration of a growing body of scholarship in the field of early childhood which is committed to thinking more generatively about 'sticky knots' (Haraway, 2008) - the 'weasel' concepts like quality, play, developmentalism, and so on that are so entrenched and seemingly impervious to critique. The various contributions to this issue have, in very different ways, sought to go beyond quality and, in doing so, have illustrated the enormously generative potentialities that post-humanist and new materialist theorising has to offer. We might go beyond, not in a quest to get it right, but to question, to make the familiar strange, and to work within the metanarratives and discursive frameworks that have hitherto acted to contain 'quality' in particularly unhelpful and potentially harmful ways. It is especially heartening to have a contribution to this debate from The Red House Children's Centre - a group of practitioners enthused by, and willing to take up, an invitation to reconfigure quality and to grapple with challenging philosophies and theories. All of the contributors to this issue have risen to the challenge of significant ontological and epistemological shifts to work with a different logic and so generate other knowledge claims that might just get us beyond normative, standardised and overly technicist conceptualisations and articulations of quality.

Liz Jones Hong Kong Institute of Education, Hong Kong Jayne Osgood Middlesex University, UK Rachel Holmes Manchester Metropolitan University, UK Mathias Urban University of Roehampton, UK

\section{References}

Barad K (2012) Interview with Karen Barad. In: Dolphijn R and Van der Tuin I (eds) New Materialism: Interviews and Cartographies. Ann Arbor, MI: Open University Press, pp. $48-70$.

Braidotti R (2012) Nomadic Theory: The Portable Rosi Braidotti. New York: Columbia University Press. Dahlberg G, Moss P and Pence A (1999) Beyond Quality in Early Childhood Education and Care: Postmodern Perspectives. London: Routledge. Dahlberg G, Moss P and Pence A (2007) Beyond Quality in Early Childhood Education and Care: Postmodern Perspectives. Rev. ed. London: Routledge. Dahlberg G, Moss P and Pence A (2013) Beyond Quality in Early Childhood Education and Care: Languages of Evaluation. 3rd ed. London: Routledge. Deleuze G and Guattari F (1994) A Thousand Plateaus. London: Athlone Press. Haraway D (2008) When Species Meet. Minneapolis, MN: University of Minnesota Press.

Jones L, Osgood J, Urban M, et al. (2014) Eu(rope): (Re)assembling, (re)casting and (re)aligning lines of de- and re-territorialisation of early childhood. International Review of Qualitative Research 7(1): 58-79.

Massumi B (1993) The Politics of Everyday Fear. Minneapolis, MN: University of Minnesota Press.

Osgood J, Scarlet RR and Giugni M (2015) Reconfiguring quality: Beyond discourses and subjectivities to matter, bodies and becomings in early childhood education. In: 
Cannella GS, Salazar Perez M and Lee I (eds) Critical Examinations of Quality in Early Education and Care. New York: Peter Lang, pp. 139-156.

Penn H (2011) Quality in Early Education and Care: An International Perspective. Maidenhead: Open University Press/McGraw Hill.

Unger RM (2005) What Should the Left Propose? London: Verso 